\title{
Screening and prevention in Swiss primary care: a systematic review
}

\author{
This article was published in the following Dove Press journal: \\ International Journal of General Medicine \\ I5 December 20II \\ Number of times this article has been viewed
}

\section{David Eisner \\ Marco Zoller \\ Thomas Rosemann \\ Carola A Huber \\ Nina Badertscher \\ Ryan Tandjung}

Institute for General Practice and Health Services Research, University of Zurich, Zurich, Switzerland
Correspondence: Ryan Tandjung Institute for General Practice and Health Services Research, University of Zurich, Pestalozzistrasse 24, 809। Zürich, Switzerland

$\mathrm{Tel}+4 \mid 442557508$

Fax +4I 442559097

Email ryan.tandjung@usz.ch
Background and objectives: Prevention is a challenging area of primary care. In Switzerland, little is known about attitudes to and performance of screening and prevention services in general practice. To implement prevention services in primary care it is important to know about not only potential facilitators but also barriers. Primary care encompasses the activities of general practitioners, including those with particular interest and/or specializations (eg, pediatrics, gynecology). The aim of this study was to review all studies with a focus on prevention services which have been conducted in Switzerland and to reveal barriers and facilitators for physicians to participate in any preventive measures.

Methods: The Cochrane Library, PubMed, EMBASE and BIOSIS were searched from January 1990 through December 2010. Studies focussing on preventive activities in primary care settings were selected and reviewed. The methodological quality of the identified studies was classified according to the guidelines in the Consolidated Standards of Reporting Trials (CONSORT) statement.

Results: We identified 49 studies including 45 descriptive studies and four randomised controlled trials (RCTs). Twelve studies addressed the prevention of epidemics, eleven out of them vaccinations. Further studies focused on lifestyle changes, physical activity counselling, smoking cessation, cardiovascular prevention and cancer screening. Perceived lack of knowledge/training and lack of time were the most commonly stated barriers. Motivation, feasibility and efficiency were the most frequently reported supporting factors for preventive activities. The methodological quality was weak, only one out of four RCTs met the applied quality criteria.

Conclusion: Most studies focussing on screening and prevention activities in primary care addressed vaccination, lifestyle modification or cardiovascular disease prevention. Identified barriers and facilitators indicate a need for primary-care-adapted education and training which are easy to handle, time-saving and reflect the specific needs of general practitioners. If new prevention programs are to be implemented in general practices, RCTs of high methodological quality are needed to assess their impact.

Keywords: disease prevention, primary care, Switzerland, epidemic, screening, education, descriptive study

\section{Background}

The WHO as well as most national health care authorities strongly recommend preventive services since there is a clear and overwhelming evidence of their effectiveness in many areas, especially in primary prevention. Primary prevention has shown to be four times as cost-effective as secondary prevention. ${ }^{1}$ Counselling and vaccinations are the most important preventive services, ${ }^{2}$ but there is also clear evidence for some 
screening procedures. Despite the fact that these services can easily be provided, especially in a primary care setting, the delivery of preventive services remains low. ${ }^{3}$

In Switzerland, prevention is a central public health objective and should therefore play a major role in general practitioners' (GPs) daily work. In consequence, over the years, several preventive programs as for example the recent "gesundheitscoaching-project" ("health coaching project") from the Swiss college of primary care physicians (KHM) have been launched. ${ }^{4}$ If new prevention programs in primary care are to be introduced successfully, it is important to know about not only potential facilitators but also barriers to implementation. So far, little is known about GPs' attitudes towards and performance of screening and prevention services in Switzerland. Several studies from the US have determined some barriers and facilitators to the performance of preventive services, ${ }^{5-9}$ namely and most importantly lack of time, along with provider forgetfulness, inconvenience and logistical difficulties, lack of expertise, lack of positive feedback, disagreement with recommendations, patient discomfort or refusal, high cost, and lack of third-party reimbursement. It remains unclear if these findings can be transferred to Switzerland. The Swiss health care system differs in many aspects, especially with regard to insurance schemes. In contrast to countries such as the US, in Switzerland all residents are insured and these insurances cover a large variety of preventive services. Therefore, the aim of this study was to review all studies with a focus on prevention services which have been conducted so far in Switzerland and to reveal the reported barriers and facilitators in Switzerland's primary care setting.

\section{Methods}

\section{Search strategy}

The databases PubMed, BIOSIS, EMBASE and the Cochrane Library were searched systematically from January 1990 through December 2010 using medical subject headings and title key words related to "prevention", "screening" and "primary care". In addition, a manual search was done for four Swiss journals ("Schweizerische Ärztezeitung", "Primary Care", "Ars Medici" and "Managed Care") which focus on primary care. The search was limited to studies performed in Switzerland and included articles in German, English and French.

\section{Inclusion and exclusion criteria}

Studies were considered relevant if they addressed screening and prevention activities (including primary, secondary and tertiary prevention) in Swiss primary care. In addition, we included studies which were conducted in settings in which a primary care provider played a key role (eg, as an author or as a study participant). Review articles, study descriptions and studies about epidemiological prevalence were excluded. The methodological quality of all included studies was assessed using the guidelines in the Consolidated Standards of Reporting Trials (CONSORT) statement. ${ }^{10}$

\section{Data extraction and validity assessment}

Data extraction was performed by one of the authors (DE) and checked independently by a second (MZ). Final extraction was decided by consensus of both. Included studies have been systematically analyzed for study motivation, topics, methods, age and gender of participants, results, conclusions, barriers and supporting factors for preventive measures and the specific role of the GP.

\section{Results \\ Description of studies}

The search of the databases yielded 1918 references, of which 49 met our inclusion criteria for detailed data abstraction (Figure 1). All studies were conducted in Switzerland and were published in German, English or French between 1990 and 2010. The main characteristics and the results are summarized and presented in Table 1. Most of the included studies were cross-sectional surveys and descriptive studies, with four randomized controlled trials (RCTs). The preventive interventions provided in the studies varied widely according to the addressed preventive subject. Twelve studies addressed the prevention of infectious diseases, especially influenza by providing vaccinations $^{11-22}$ or by performing a specific diagnostic test. ${ }^{22}$ For clinical topics, most prevention activities addressed cardiovascular disease prevention, ${ }^{23-30}$ cancer screening, ${ }^{31-34} \mathrm{HIV},{ }^{35-37}$ prevention of osteoporosis, ${ }^{38,39}$ addiction prevention, ${ }^{40,41}$ and others $^{42-47}$ (Table 2). The most common observed intervention was counseling on lifestyle changes with twelve studies. ${ }^{30,48-59}$ Among them, six addressed counselling about physical activity and two dealt with smoking cessation. Most of the studies addressed specific age groups or patient characteristics, such as influenza vaccination in people older than 65 years, or enhancing physical activity in patients younger than 65 years.

\section{Methodological quality}

Our review revealed a remarkable number of studies performed in Swiss primary care with a focus on preventive services. Most of these studies did not define a clear intervention and did not define clear clinical outcomes or process parameters.

Only six studies were two-armed studies with a defined control and intervention group. Of these six only four studies reported a randomization process. In consequence, only four 


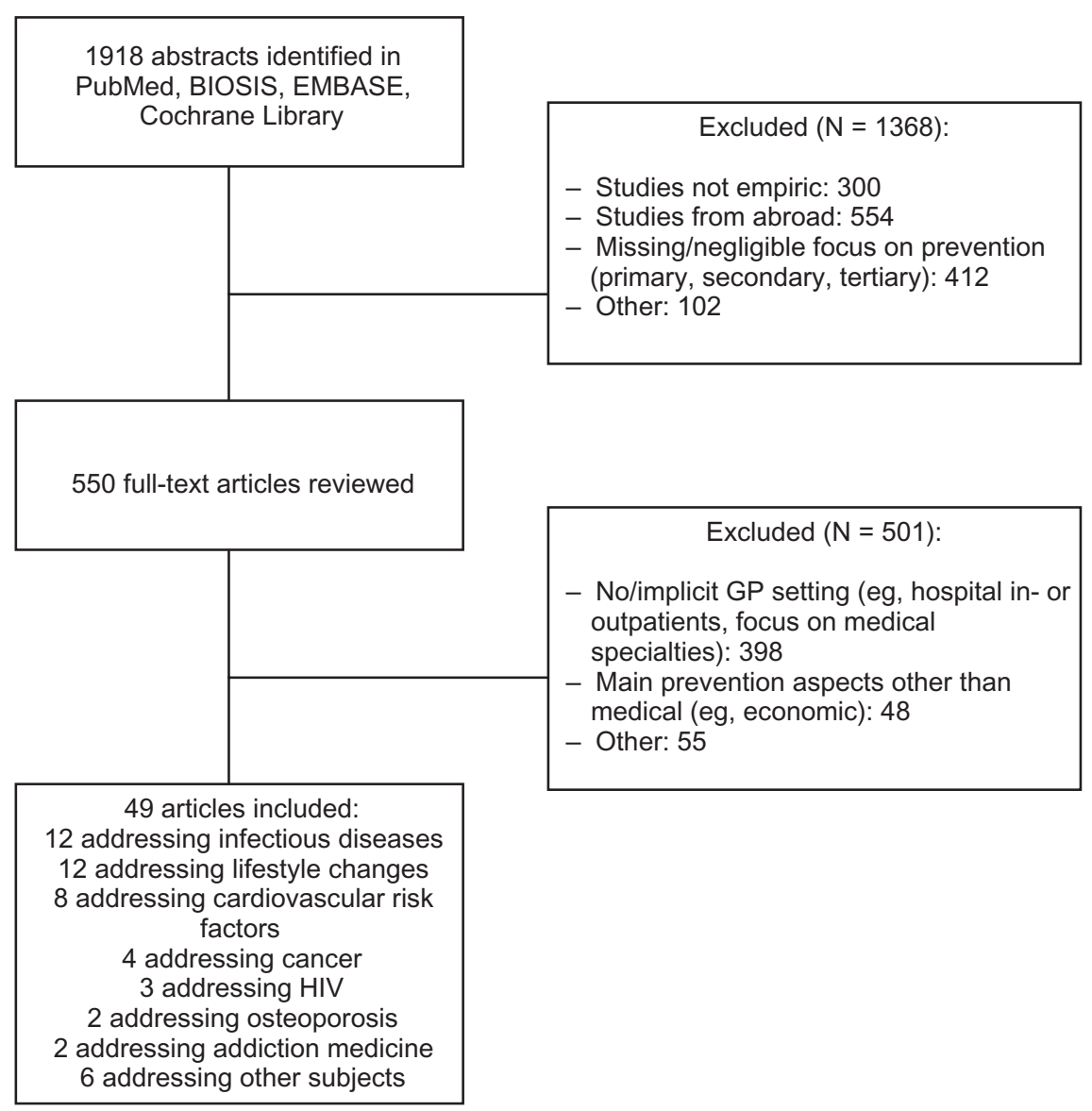

Figure I Search strategy and article review process.

studies fulfilled the criteria for a randomized controlled trial (RCT). ${ }^{41,48,51,53}$ Detailed information is displayed in Table 1.

In order to assess the methodological quality of the included RCTs, we used the guidelines in the Consolidated Standards of Reporting Trials (CONSORT) statement. ${ }^{10}$ Overall, the methodological quality was weak. None of the RCTs fulfilled all of the CONSORT criteria. The best study fulfilled 30 out of 37 checklist items. ${ }^{53}$ Two of the remaining three RCTs met more than half and one of the RCTs met less than half of the criteria.

\section{Barriers}

Table 3 displays the most frequently mentioned barriers in screening and prevention services from a GP's as well as from a patient's perspective.

\section{Barriers from GP's perspective}

Thirty nine studies reported any barriers which precluded GPs from performing screening and prevention services. ${ }^{12,13,15-17,19-22,24-27,29-33,35,36,39-53,55,57-59}$ The most frequently cited barriers were "lack of knowledge/skills"

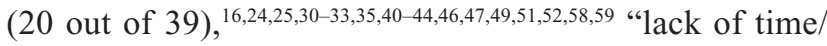
high workload" (11 out of 39) 12,29,30,32,33,43,48,51,53,55,59 and “own disbeliefs" (9 out of 39). ${ }^{17,19,25,30,39-41,50,57}$

\section{Lack of knowledge/skills}

Lack of knowledge or skills was the most common reported barrier and mentioned in studies with completely different clinical targets, eg, in studies addressing cardiovascular risk factors, ${ }^{24,25,30}$ cancer prevention, ${ }^{31,33}$ addiction prevention $^{40,41}$ or in different prevention interventions for infectious diseases. ${ }^{16,35}$ The main barrier reported was the lack of specific communication skills for counselling in lifestyle changes ${ }^{43,49}$ and insufficient routine in specific counselling. ${ }^{51,58,59}$ Insufficient sources of information were mentioned, eg, in the field of advice-giving for travelling. ${ }^{52}$ Five further studies on different areas of prevention also reported a lack of knowledge and skills as a barrier. ${ }^{42-44,46,47}$

\section{Lack of time/high workload}

Time constraints were found in several studies, independent of the prevention focus. ${ }^{29,30,32}$ Five studies focusing 
Table I Key features of studies included in the systematic review

\begin{tabular}{|c|c|c|c|c|c|}
\hline \multirow[t]{2}{*}{ Reference } & \multirow[t]{2}{*}{ Prevention } & \multirow[t]{2}{*}{ Intervention } & \multicolumn{2}{|c|}{ Participants } & \multirow{2}{*}{$\frac{\text { Barriers }}{\text { Providers (GPs) }}$} \\
\hline & & & $\begin{array}{l}\text { No of } \\
\text { providers }\end{array}$ & $\begin{array}{l}\text { No of } \\
\text { patients }\end{array}$ & \\
\hline $\begin{array}{l}\text { Allenspach } \\
\text { et } \mathrm{a}^{48}\end{array}$ & 2 & $\begin{array}{l}\text { Physical activity counselling } \\
\text { depending on the current } \\
\text { level of physical activity }\end{array}$ & 40 & 4987 & $\begin{array}{l}\text { Workload, time constraints, disturbance, } \\
\text { of daily routine, too complex project } \\
\text { organisation, doubts about the own } \\
\text { counselling abilities }\end{array}$ \\
\hline Bally et $\mathrm{al}^{30}$ & 3 & $\begin{array}{l}\text { Retrospective analysis } \\
\text { of adherence to plasma } \\
\text { cholesterol management } \\
\text { guidelines }\end{array}$ & 20 & 866 & $\begin{array}{l}\text { Relevant comorbidity, priority of other } \\
\text { disease, belief that risk doesn't require } \\
\text { screening (acceptance and knowledge } \\
\text { of guidelines), forgetting to follow } \\
\text { guidelines, lack of time }\end{array}$ \\
\hline $\begin{array}{l}\text { Birchmeier } \\
\text { et al" }\end{array}$ & 1 & $\begin{array}{l}\text { Vaccination counselling by } \\
\text { a healthcare professional }\end{array}$ & 5 & 5 & $\begin{array}{l}\text { Medical contraindication, need for an } \\
\text { additional person }\end{array}$ \\
\hline
\end{tabular}

$\begin{array}{ll}\text { Bovier } & \text { I } \\ \text { et al }{ }^{12} & \begin{array}{l}\text { Questionnaire about } \\ \text { attitudes and use of } \\ \text { recommended vaccinations }\end{array}\end{array}$

\begin{tabular}{|c|c|c|c|}
\hline $\begin{array}{l}\text { Bovier } \\
\text { et } \mathrm{al}^{13}\end{array}$ & I & $\begin{array}{l}\text { Mail survey about missed } \\
\text { opportunities for vaccination } \\
\text { in adults, regarding patients' } \\
\text { perceptions and GPs' } \\
\text { recommendations }\end{array}$ & 123 \\
\hline $\begin{array}{l}\text { Bovier } \\
\text { et } \mathrm{al}^{49}\end{array}$ & 2 & $\begin{array}{l}\text { Review of medical files } \\
\text { regarding adherence } \\
\text { to diabetes care guidelines }\end{array}$ & 186 \\
\hline $\begin{array}{l}\text { Brunner-La } \\
\text { Rocca/Marti }\end{array}$ & 3 & $\begin{array}{l}\text { Patients' questionnaire about } \\
\text { after care following } \\
\text { myocardial infarction }\end{array}$ & 83 \\
\hline $\begin{array}{l}\text { Bucher } \\
\text { et a }{ }^{42}\end{array}$ & 8 & $\begin{array}{l}\text { Determination of the effect } \\
\text { of study results reporting } \\
\text { using either the relative } \\
\text { or the absolute risk reduction }\end{array}$ & 802 \\
\hline $\begin{array}{l}\text { Cerletti-Knusel } \\
\text { et } \mathrm{al}^{24}\end{array}$ & 3 & $\begin{array}{l}\text { Assessment of knowledge } \\
\text { in terms of endocarditis } \\
\text { prophylaxis }\end{array}$ & $\begin{array}{l}285 \text { (I64 } \\
\text { dentists, } \\
\text { I2I PCP) }\end{array}$ \\
\hline $\begin{array}{l}\text { Cornuz } \\
\text { et } \mathrm{al}^{43}\end{array}$ & 8 & $\begin{array}{l}\text { Determination of the relative } \\
\text { importance of certain barriers } \\
\text { to preventive interventions } \\
\text { and exploration of the } \\
\text { association between } \\
\text { physicians' characteristics } \\
\text { and their attitudes towards } \\
\text { prevention }\end{array}$ & 496 \\
\hline Eckert/Junker ${ }^{50}$ & 2 & $\begin{array}{l}\text { Investigation about } \\
\text { smoking cessation } \\
\text { management by GPs }\end{array}$ & \\
\hline
\end{tabular}

93

Lack of time, lack of patient interest, lack three alcoholic drinks per day, sedentary
Misinterpretation of different variables expressing the same result, lack of training

Knowledge of training, consumption of more than lifestyle, lack of national certification and lack of awareness of their own blood pressure

No time to verify vaccination status and convince patient to be immunized and other logistic issues related to physician's practice, patients expressing personnel Lack of clear national objectives and guidelines regarding the prevention of vaccine-preventable diseases, area of residence

Documentation of family and personal history and of lipid profile, specific communication and counselling skills

(a)

Weak belief in the efficacy of short counselling 


\begin{tabular}{llll}
\hline Patients & Supporting factors & Study design & $\begin{array}{l}\text { Methodological quality of } \\
\text { RCTs: fulfilled CONSORT } \\
\text { Providers (GPs) }\end{array}$ \\
criteria*
\end{tabular}

Time, interest

Refusal to take drugs

Medical contraindication, need for an additional person
Personal contacts of the project team's colleagues, manageable workload, agreement with the project's idea and practical implementation, own physical activity

Positive predictors for overall guideline adherence were cardiovascular event in family and elevated triglycerides

Medical contraindication, patient's own choice put into question

Own positive attitudes towards vaccination, regular use of the different sources of information, readiness to take responsibility

French-speaking region, promotion campaigns perceived usefulness, opinion, lack of physician's encouragement, lack of efficacy of the influenza vaccination

Lack of time to focus on the patient's individual needs

Education, knowledge

Lack of interest

Missing advice from the physician, missing wish to stop
Risk of relapse (smoking), fear

Training, techniques to tailor information in a differentiated way

Knowledge, guidelines

Acknowledgment of the responsibility for prevention, high motivation to implement prevention in the daily practice, consciousness of patients' expectations regarding prevention

Patients' expectation of being asked about smoking, guidelines, short counselling with good effects
Patients' interest

Professional's aid, advice, reminder letter, organizational and administrative strategies, feasibility and effectiveness

Patient's perceived usefulness of vaccination and opinion, age
Ib, 2a, 2b, 3a, 4a, 4b, 5, 6a, 8b,

IIa, IIb, I2a, I2b, I3a, I5, I6,

I7a, I7b, I8, 21, 22, 23, 24, 25

Education and instruction

Physician's advice, poor

health status, heavy

smoking, intention to 
Table I (Continued)

\begin{tabular}{|c|c|c|c|c|c|}
\hline \multirow[t]{2}{*}{ Reference } & \multirow[t]{2}{*}{ Prevention } & \multirow[t]{2}{*}{ Intervention } & \multicolumn{2}{|l|}{ Participants } & \multirow{2}{*}{$\frac{\text { Barriers }}{\text { Providers (GPs) }}$} \\
\hline & & & $\begin{array}{l}\text { No of } \\
\text { providers }\end{array}$ & $\begin{array}{l}\text { No of } \\
\text { patients }\end{array}$ & \\
\hline Eichler et $\mathrm{al}^{25}$ & 3 & $\begin{array}{l}\text { Evaluation of barriers } \\
\text { impeding the application } \\
\text { of cardiovascular prediction } \\
\text { rules in primary prevention }\end{array}$ & $\begin{array}{l}356 \\
\text { questionnaires }\end{array}$ & & $\begin{array}{l}\text { Restricted acceptance and trust: doubts } \\
\text { concerning over-simplification of risk } \\
\text { assessment, lack of knowledge, distrust } \\
\text { in validity, distrust in stakeholders, } \\
\text { distrust in concept of prevention, lack } \\
\text { of practicability }\end{array}$ \\
\hline Escher/Sappino ${ }^{31}$ & 4 & $\begin{array}{l}\text { Assessment of physicians' } \\
\text { knowledge, attitude and } \\
\text { perception of their role } \\
\text { towards testing for hereditary } \\
\text { breast and ovarian cancer }\end{array}$ & 243 & & $\begin{array}{l}\text { Feeling unsure about testing, testing } \\
\text { incorrect without approved strategies } \\
\text { for the prevention and detection of early } \\
\text { breast cancer; testing could do more } \\
\text { harm than good }\end{array}$ \\
\hline Etter et $\mathrm{al}^{51}$ & 2 & $\begin{array}{l}\text { Testing of the acceptability } \\
\text { and effectiveness of mailing } \\
\text { "Smoker" stickers to private } \\
\text { practitioners (and its } \\
\text { influence on smoking } \\
\text { cessation counselling) }\end{array}$ & 497 & & $\begin{array}{l}\text { Lack of time, lack of patient interest, lack } \\
\text { of training, consumption of more than } \\
\text { three alcoholic drinks per day, sedentary } \\
\text { lifestyle, lack of national certification } \\
\text { and lack of awareness of their own } \\
\text { blood pressure, relative importance } \\
\text { of different barriers varies across } \\
\text { different preventive interventions }\end{array}$ \\
\hline Gaspoz et $\mathrm{al}^{26}$ & 3 & $\begin{array}{l}\text { Analysis of the impact of a } \\
\text { public campaign on chest pain } \\
\text { on physicians involved in the } \\
\text { prehospital care (physician } \\
\text { delay, rates of immediate } \\
\text { hospitalization, transportation } \\
\text { by ambulance) }\end{array}$ & & $\begin{array}{l}749 \text { before, } \\
866 \text { after } \\
\text { the campaign }\end{array}$ & $\begin{array}{l}\text { Insufficient integration of the campaign } \\
\text { organization into the healthcare delivery } \\
\text { process of GPs }\end{array}$ \\
\hline Gasser et $\mathrm{al}^{38}$ & 6 & $\begin{array}{l}\text { Validation of a case finding } \\
\text { strategy for postmenopausal } \\
\text { women who would benefit } \\
\text { most from subsequent DXA } \\
\text { measurement }\end{array}$ & 90 & 382 & \\
\hline Gauthey et $\mathrm{al}^{14}$ & 1 & $\begin{array}{l}\text { Evaluation of flu vaccination } \\
\text { coverage of the geriatric } \\
\text { population living in the } \\
\text { community }\end{array}$ & & 1010 & \\
\hline Götschi et al ${ }^{29}$ & 3 & $\begin{array}{l}\text { Experiences with a program } \\
\text { for patients with coronary } \\
\text { artery disease: patient } \\
\text { identification, measuring } \\
\text { of performance, recruitment } \\
\text { and motivation of patients } \\
\text { for a CAD-training }\end{array}$ & & $\begin{array}{l}\text { Practice A: 66; } \\
\text { practice B: II4 }\end{array}$ & Time needed, administrative efforts \\
\hline Gugelmann et al ${ }^{15}$ & I & $\begin{array}{l}\text { Evaluation of hepatitis } B \\
\text { vaccination attitudes } \\
\text { referred to existing } \\
\text { guidelines }\end{array}$ & 62 & & $\begin{array}{l}\text { Lack of information about epidemiology, } \\
\text { concerns about long-term efficiency and } \\
\text { safety of the vaccine, cost-effectiveness- } \\
\text { relation perceived as unfavorable }\end{array}$ \\
\hline Haller et $\mathrm{al}^{58}$ & 2 & $\begin{array}{l}\text { Brief intervention using } \\
\text { a motivational interviewing } \\
\text { style and a guide known as } \\
\text { the 5A's. Training sessions } \\
\text { with actors }\end{array}$ & 7 & 76 & $\begin{array}{l}\text { Being unprepared for dealing with } \\
\text { a diagnosed cannabis dependence }\end{array}$ \\
\hline
\end{tabular}




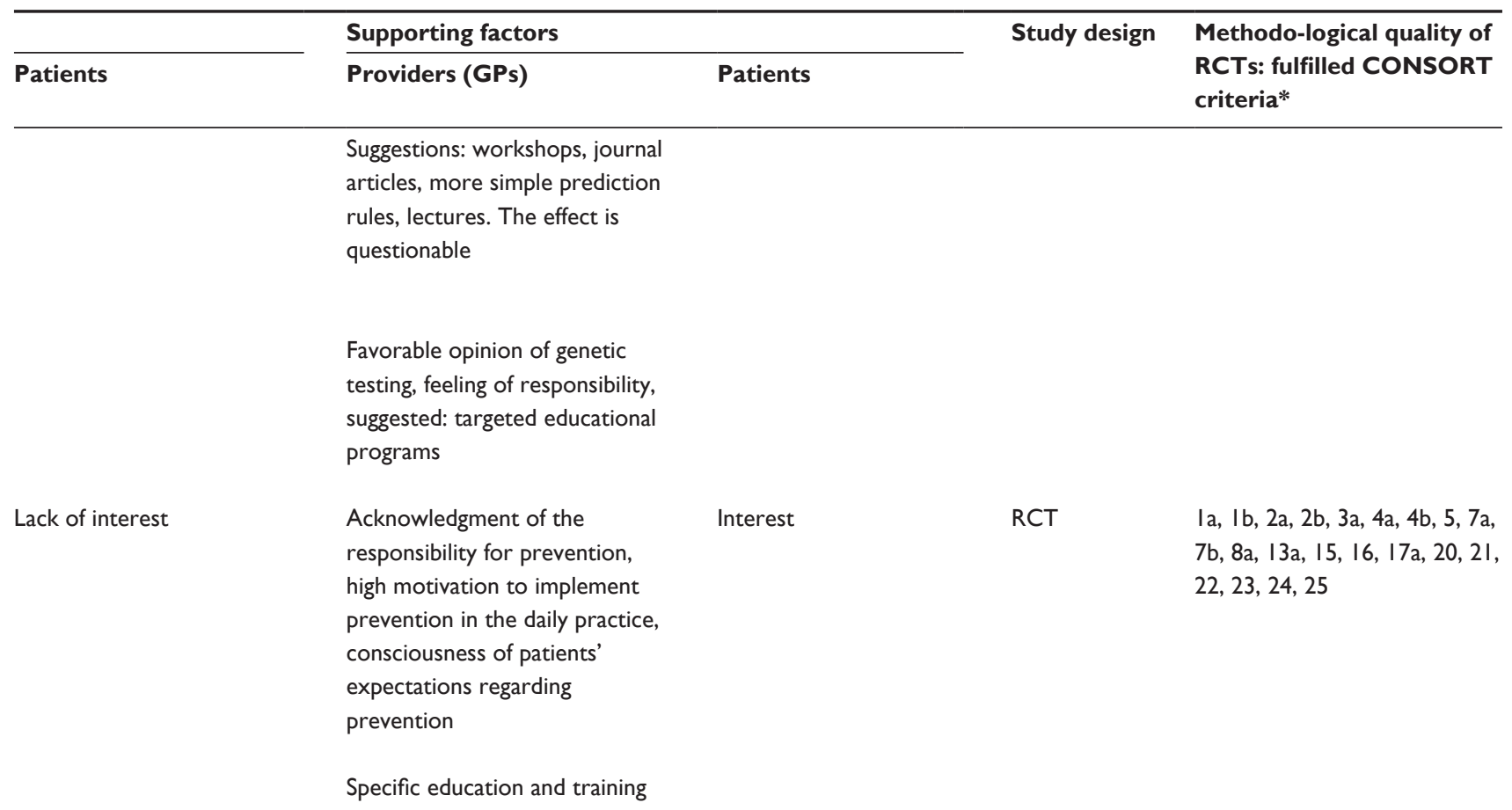

Phalangeal measurement site easily accessible, widespread access to conventional $\mathrm{x}$-ray

devices

Rarely affected by flu, "good health", no recommendation, fear of vaccination side effects, doubts about the effectiveness, information, little knowledge Recently absolved rehabilitation program, feeling to be too old to participate

Useful tool in chronic disease management, network
Better diagnosis, cost-efficiency

Physician's advice and information, information in general synergies, additional personnel

Older children or adolescents, combined vaccines

Being flexible in time schedule, good feasibility and usefulness, benefit from training
Confidentiality 
Table I (Continued)

\begin{tabular}{|c|c|c|c|c|c|}
\hline \multirow[t]{2}{*}{ Reference } & \multirow[t]{2}{*}{ Prevention } & \multirow[t]{2}{*}{ Intervention } & \multicolumn{2}{|l|}{ Participants } & \multirow{2}{*}{$\begin{array}{l}\text { Barriers } \\
\text { Providers (GPs) }\end{array}$} \\
\hline & & & $\begin{array}{l}\text { No of } \\
\text { providers }\end{array}$ & $\begin{array}{l}\text { No of } \\
\text { patients }\end{array}$ & \\
\hline Hasse et $\mathrm{al}^{16}$ & I & $\begin{array}{l}\text { Evaluation of anti-infectious } \\
\text { strategies after splenectomy, } \\
\text { assessment of adherence } \\
\text { to vaccination guidelines, } \\
\text { the use of antibiotics and } \\
\text { the awareness of the } \\
\text { infectious risks }\end{array}$ & 32 & 91 & $\begin{array}{l}\text { Misunderstandings concerning } \\
\text { vaccination between hospital doctors } \\
\text { and GPs, lack of guidelines for antibiotic } \\
\text { prophylaxis, lack of knowledge }\end{array}$ \\
\hline Hatz et $\mathrm{al}^{52}$ & 2 & $\begin{array}{l}\text { Survey about knowledge, } \\
\text { sources of information } \\
\text { and the needs of physicians } \\
\text { regarding travel advice }\end{array}$ & 300 & & $\begin{array}{l}\text { (Updated) knowledge, adequate sources } \\
\text { of information }\end{array}$ \\
\hline Hausser/Jeangros ${ }^{44}$ & 8 & $\begin{array}{l}\text { Evaluation of preventive } \\
\text { activities in ambulatory } \\
\text { care among self-employed } \\
\text { physicians }\end{array}$ & 191 & 7482 & $\begin{array}{l}\text { Lack of adequate training, modes } \\
\text { of payment for medical acts, own } \\
\text { effectiveness not that evident }\end{array}$ \\
\hline Hayoz et $\mathrm{al}^{27}$ & 3 & $\begin{array}{l}\text { Investigation of the Ankle/ } \\
\text { Brachial Pressure Index (ABI) } \\
\text { for its suitability in daily } \\
\text { practice to identify patients } \\
\text { at atherothrombotic risk }\end{array}$ & 276 & 25,351 & $\begin{array}{l}\text { Underestimation or missing recognition } \\
\text { of atherothrombotic risks }\end{array}$ \\
\hline Huguenin et $\mathrm{al}^{32}$ & 4 & $\begin{array}{l}\text { Assessment of the knowledge, } \\
\text { attitudes and practices of } \\
\text { women in respect to breast } \\
\text { cancer and its prevention. } \\
\text { The present study focuses on } \\
\text { access by women to medical } \\
\text { preventive measures }\end{array}$ & NR & 382 & Embarrassment, lack of time \\
\hline Jimmy/Martin 53 & 2 & $\begin{array}{l}\text { Investigation of physical } \\
\text { activity based on the } \\
\text { transtheoretical model (TM) } \\
\text { of behaviour change }\end{array}$ & 5 & 132 & Some increase of workload \\
\hline Krause et $\mathrm{al}^{54}$ & 2 & $\begin{array}{l}\text { Assessment of the awareness } \\
\text { of the risk of rabies for } \\
\text { travelers, and of the relevant } \\
\text { preventive measures }\end{array}$ & $\begin{array}{l}\text { I50 Swiss, } \\
\text { I50 German }\end{array}$ & & \\
\hline $\begin{array}{l}\text { Malinverni } \\
\text { et } \mathrm{al}^{35}\end{array}$ & 5 & $\begin{array}{l}\text { Questionnaire about } \\
\text { current practice, attitudes } \\
\text { and knowledge on care, } \\
\text { prevention and treatment of } \\
\text { HIV infection and HIV-related } \\
\text { problems }\end{array}$ & 688 & & $\begin{array}{l}\text { Lack of medical skills and knowledge, } \\
\text { fear of own infection (or of the } \\
\text { personnel), difficulty to address } \\
\text { the topic }\end{array}$ \\
\hline $\begin{array}{l}\text { Marki } \\
\text { et } \mathrm{al}^{55} \text { (a) }\end{array}$ & 2 & $\begin{array}{l}\text { Systematic counselling by } \\
\text { general practitioners for } \\
\text { promoting physical activity } \\
\text { in elderly patients }\end{array}$ & 2 & 29 & Lack of time, paperwork \\
\hline $\begin{array}{l}\text { Marki } \\
\text { et } \mathrm{al}^{56}(\mathrm{~b})\end{array}$ & 2 & $\begin{array}{l}\text { Development and testing of } \\
\text { a counselling program based } \\
\text { on the Transtheoretical } \\
\text { Model of behavioral change }\end{array}$ & 33 & 448 & \\
\hline
\end{tabular}




\begin{tabular}{|c|c|}
\hline & Supporting factors \\
\hline Patients & Providers (GPs) \\
\hline \multicolumn{2}{|c|}{$\begin{array}{l}\text { Lack of knowledge and } \\
\text { education }\end{array}$} \\
\hline \multirow[t]{2}{*}{ Compliance } & $\begin{array}{l}\text { Interest in the provision of } \\
\text { information and awareness } \\
\text { of the need for improved } \\
\text { information; vaccination } \\
\text { schedules; requested: checklist, } \\
\text { information leaflets on malaria } \\
\text { and medical journals } \\
\text { Own motivation }\end{array}$ \\
\hline & $\begin{array}{l}\mathrm{ABI} \text { : easy to use and to } \\
\text { integrate in the daily routine, } \\
\text { cost-effective, non-invasive, no } \\
\text { radiation exposure, no allergic } \\
\text { reactions, higher awareness }\end{array}$ \\
\hline
\end{tabular}

Lack of information

Symptoms of pain (rheumatism, back pain), lack of time, lack of interest

Physician's awareness

Poor motivation, already high level of physical activity

Health problems (already high level of physical activity)

Published recommendations
Handling of the counselling protocol was considered easy

Nurse

\begin{abstract}
Education programs, experience in treating HIV-patients

on travel advice
\end{abstract}

Study design Methodo-logical quality of RCTs: fulfilled CONSORT criteria*

Knowledge, being

informed

Compliance, leaflets

Information

Good and useful

perception of the

project, being given an

incentive to get moving

(brief feedback)

Physician's awareness
RCT

Ib, 2a, 2b, 3a, 4a, 4b, 5, 6a, 8a, $8 b, 9,10,11 a, 11 b, 12 a, 12 b$,

13a, 13b, 14a, 14b, 15, 16, 17a, I7b, I8, 2I, 22, 23, 24, 25
Tailored information materials

Good acceptance of the program 
Table I (Continued)

\begin{tabular}{|c|c|c|c|c|c|}
\hline \multirow[t]{2}{*}{ Reference } & \multirow[t]{2}{*}{ Prevention } & \multirow[t]{2}{*}{ Intervention } & \multicolumn{2}{|l|}{ Participants } & \multirow{2}{*}{$\begin{array}{l}\text { Barriers } \\
\text { Providers (GPs) }\end{array}$} \\
\hline & & & $\begin{array}{l}\text { No of } \\
\text { providers }\end{array}$ & $\begin{array}{l}\text { No of } \\
\text { patients }\end{array}$ & \\
\hline $\begin{array}{l}\text { Matter } \\
\text { et } \text { al }^{17}\end{array}$ & I & $\begin{array}{l}\text { Evaluation of the impact } \\
\text { of the Swiss MMR vaccination } \\
\text { campaign (started in 1987) } \\
\text { on disease frequency }\end{array}$ & $150-200$ & $>200$ & Mumps vaccine quality \\
\hline Matter et al ${ }^{18}$ & I & $\begin{array}{l}\text { Monitoring clinical pertussis } \\
\text { over time }\end{array}$ & $150-200$ & & \\
\hline $\begin{array}{l}\text { Meystre-Agustoni } \\
\text { et } \mathrm{al}^{36}\end{array}$ & 5 & $\begin{array}{l}\text { Prevention practices of } \\
\text { primary health care physicians } \\
\text { in Switzerland in the context } \\
\text { of the HIV/Aids epidemic: } \\
\text { changes between } 1990 \\
\text { and } 2002\end{array}$ & $\begin{array}{l}1212(2002) \\
791 \text { (1995); } \\
699(1990)\end{array}$ & & $\begin{array}{l}\text { Sexual/drug history taking as a delicate } \\
\text { topic, limitation of investigations } \\
\text { to classic risk constellation }\end{array}$ \\
\hline $\begin{array}{l}\text { Moiradat Rytz } \\
\text { et al }{ }^{19}\end{array}$ & I & $\begin{array}{l}\text { Questionnaire about the } \\
\text { use of vaccination against } \\
\text { influenza in the hospital milieu } \\
\text { and by family physicians in } \\
\text { Fribourg in 1997: facts and } \\
\text { opinions }\end{array}$ & $\begin{array}{l}104 \text { GPs, } \\
19 \text { clinicians }\end{array}$ & 383 & $\begin{array}{l}\text { Oblivion of vaccination, patient refusal, } \\
\text { disagreement with official guidelines }\end{array}$ \\
\hline $\begin{array}{l}\text { Muntwyler } \\
\text { et } \mathrm{al}^{28}\end{array}$ & 3 & $\begin{array}{l}\text { National survey on } \\
\text { prescription of cardiovascular } \\
\text { drugs among outpatients with } \\
\text { coronary artery disease } \\
\text { in Switzerland }\end{array}$ & 650 & 565 & \\
\hline Page et $\mathrm{al}^{37}$ & 5 & $\begin{array}{l}\text { Study about the quality } \\
\text { of generalist versus speciality } \\
\text { care for people with HIV } \\
\text { on antiretroviral treatment }\end{array}$ & $\begin{array}{l}10 \text { GPs, } \\
6 \text { clinicians }\end{array}$ & 120 & \\
\hline Pelet et $\mathrm{al}^{40}$ & 7 & $\begin{array}{l}\text { Evaluation of governmental } \\
\text { policies of easier and } \\
\text { increased access to MMT } \\
\text { in Vaud }\end{array}$ & 236 & 1782 & $\begin{array}{l}\text { Difficult management, comorbidity, } \\
\text { lack of knowledge about adequate } \\
\text { methadone dosage; ambivalence about } \\
\text { methadone, treating unstable patients }\end{array}$ \\
\hline $\begin{array}{l}\text { Peltenburg } \\
\text { et } \mathrm{al}^{45}\end{array}$ & 8 & $\begin{array}{l}\text { Survey about preserving } \\
\text { vision in the elderly: quality } \\
\text { development program in } \\
\text { general practice }\end{array}$ & 107 & 4918 & $\begin{array}{l}\text { Implementation and awareness } \\
\text { of ophthalmological concerns }\end{array}$ \\
\hline Perdrix et $\mathrm{al}^{4 !}$ & 7 & $\begin{array}{l}\text { Detection of alcoholism in } \\
\text { general practice: Applicability } \\
\text { of the CAGE test by the } \\
\text { general practitioner }\end{array}$ & 12 & 416 & $\begin{array}{l}\text { Negative perception of the test (partly } \\
\text { as useless, eg, If clinical evaluation was } \\
\text { clear enough), delicate topic for the first } \\
\text { consultation and relationship to patients, } \\
\text { own attitude, education }\end{array}$ \\
\hline Pichert et $\mathrm{al}^{33}$ & 4 & $\begin{array}{l}\text { Questionnaires about Swiss } \\
\text { primary care physicians' } \\
\text { knowledge, attitudes and } \\
\text { perception towards genetic } \\
\text { testing for hereditary breast } \\
\text { cancer }\end{array}$ & 1391 & & $\begin{array}{l}\text { Lack of knowledge, time, high workload, } \\
\text { limitations of providing genetic services } \\
\text { at the primary care level, understanding } \\
\text { of risks and benefits is still very } \\
\text { insufficient }\end{array}$ \\
\hline Praz et $\mathrm{al}^{34}$ & 5 & $\begin{array}{l}\text { Questionnaires about } \\
\text { screening of the prostate } \\
\text { cancer }\end{array}$ & 204 & & \\
\hline Ramseier $^{46}$ & 8 & $\begin{array}{l}\text { Survey on the observance } \\
\text { of the international guidelines } \\
\text { for relapse in acute and long- } \\
\text { term treatment of depression } \\
\text { and schizophrenia }\end{array}$ & 176 & & Lack of knowledge \\
\hline
\end{tabular}




\begin{tabular}{|c|c|c|c|c|}
\hline & Supporting factor & & Study design & Methodo-logical quality of \\
\hline Patients & Providers (GPs) & Patients & & $\begin{array}{l}\text { RCTs: fulfilled CONSORT } \\
\text { criteria* }\end{array}$ \\
\hline
\end{tabular}

Lower vaccination coverage

in the Romandie

Fear of side effects, disbelief in necessity
Overall high opinion of the vaccine efficacy and tolerance

Patient's' history of myocardial infarction and coronary revascularization, guidelines

Bad health status, bad healthrelated quality of life, health care model

High motivation, specialized knowledge, communication skills, cooperation with
Conviction of responsibility in HIV prevention specialists

Treatment program

Cooperation with ophthalmologists, special skills

Possible way to tackle an undetected/denied alcohol problem, own attitude, education, being in an public institution

Knowledge and awareness of complexity, favorable attitudes and readiness to play a central role in every part of the genetic counseling and testing process

Guidelines

Guidelines
High vaccination coverage

Patients' motivation to comply with the medication

Choice of an individual health care model

Easy access, lowthreshold management; high level of integration in the social framework
Ib, 2a, 2b, 3a, 4a, 4b, 5, 7a, $12 \mathrm{a}, 13 \mathrm{a}, 16,17 \mathrm{a}, 20,21$, 
Table I (Continued)

\begin{tabular}{|c|c|c|c|c|c|}
\hline \multirow[t]{2}{*}{ Reference } & \multirow[t]{2}{*}{ Prevention } & \multirow[t]{2}{*}{ Intervention } & \multicolumn{2}{|c|}{ Participants } & \multirow{2}{*}{$\frac{\text { Barriers }}{\text { Providers (GPs) }}$} \\
\hline & & & $\begin{array}{l}\text { No of } \\
\text { providers }\end{array}$ & $\begin{array}{l}\text { No of } \\
\text { patients }\end{array}$ & \\
\hline $\begin{array}{l}\text { Richard } \\
\text { et } \mathrm{al}^{20}\end{array}$ & I & $\begin{array}{l}\text { Evaluation of the performance } \\
\text { of sentinel and mandatory- } \\
\text { based surveillance systems } \\
\text { for measles in Switzerland } \\
\text { (comparison of both systems } \\
\text { in terms of their aptitude to } \\
\text { promote measles elimination) }\end{array}$ & 230 & & $\begin{array}{l}\text { Reporting system, reporting compliance, } \\
\text { unclear diagnosis criteria }\end{array}$ \\
\hline Schmid et $\mathrm{al}^{59}$ & 2 & $\begin{array}{l}\text { Evaluation of two procedures } \\
\text { to tackle physical inactivity: } \\
\text { counselling and mailing }\end{array}$ & 12 & 38 & $\begin{array}{l}\text { Little routine, time pressure, personal } \\
\text { obstacles of the physician, physical } \\
\text { activity promotion alone perceived } \\
\text { as too specific }\end{array}$ \\
\hline Sebo et $\mathrm{al}^{57}$ & 2 & $\begin{array}{l}\text { Cross-sectional assessment } \\
\text { of diabetes care in order } \\
\text { to identify diabetic patients' } \\
\text { characteristics and medical } \\
\text { care factors associated with } \\
\text { recommended glycemic } \\
\text { control (HbAlc } \leq 7 \%)\end{array}$ & 204 & 366 & Quality of care, motivation \\
\hline $\begin{array}{l}\text { Steurer-Stey } \\
\text { et } \mathrm{al}^{47}\end{array}$ & 8 & $\begin{array}{l}\text { Investigation of physicians' } \\
\text { knowledge of the principles } \\
\text { and implementation of self- } \\
\text { management in asthma care }\end{array}$ & 1039 & & $\begin{array}{l}\text { Inadequate financial compensation, } \\
\text { lack of training }\end{array}$ \\
\hline Stoll et $\mathrm{al}^{39}$ & 6 & $\begin{array}{l}\text { Self-reflection about the } \\
\text { implementation of guidelines } \\
\text { in osteoporosis management }\end{array}$ & $\begin{array}{l}13 \text { (1996), } \\
14 \text { (1997) }\end{array}$ & $\begin{array}{l}53(1996) \\
116(1997)\end{array}$ & $\begin{array}{l}\text { No regular follow-ups, no clear } \\
\text { indication for therapy, skepticism } \\
\text { against guidelines }\end{array}$ \\
\hline $\begin{array}{l}\text { Vaudaux/ } \\
\text { Steinemann }\end{array}$ & I & $\begin{array}{l}\text { Assessment of Swiss } \\
\text { physicians' knowledge on } \\
\text { hepatitis B, their perception } \\
\text { of parental information } \\
\text { concerning this infection, } \\
\text { their attitude towards } \\
\text { planned universal vaccination, } \\
\text { and their agreement } \\
\text { with different universal } \\
\text { immunization scenarios }\end{array}$ & 2506 & & $\begin{array}{l}\text { Logistic problems arising from the } \\
\text { administration of three doses within } \\
\text { two subsequent school years }\end{array}$ \\
\hline $\begin{array}{l}\text { Wunderli } \\
\text { et } \mathrm{al}^{22}\end{array}$ & I & $\begin{array}{l}\text { Assessment of the use of a } \\
\text { 'near patient' test for rapid } \\
\text { antigen detection to obtain } \\
\text { the more timely acquisition } \\
\text { of data for the surveillance } \\
\text { of influenza epidemics }\end{array}$ & 253 & & $\begin{array}{l}\text { Lower sensitivity of the rapid test, } \\
\text { results not always accurate }\end{array}$ \\
\hline
\end{tabular}

on preventive lifestyle changes reported a lack of time as a major barrier in counselling regarding physical activity, ${ }^{48,53,55}$ cannabis use, smoking cessation or alcohol reduction. ${ }^{43,51,59}$

A study addressing the prevention of hepatitis B by providing vaccination stated a lack of time to verify vaccination status and to convince patients to be immunised. ${ }^{12}$

\section{Own disbeliefs}

Own disbeliefs were a barrier found in many studies. This includes reluctance to use tests, eg, a detection-test of alcoholism; ${ }^{41}$ ambivalence about the use of methadone in patients with drug use disorders, ${ }^{40}$ disbeliefs in the quality of interventions, ${ }^{17}$ or in their necessity; ${ }^{25,30}$ or skepticism about current guidelines. ${ }^{19,39}$ 


\begin{tabular}{llll}
\hline Patients & $\begin{array}{lll}\text { Supporting factors } & \text { Study design } & \begin{array}{l}\text { Methodo-logical quality of } \\
\text { RCTs: fulfilled CONSORT } \\
\text { Providers (GPs) }\end{array} \\
\text { criteria* }\end{array}$ \\
\hline
\end{tabular}

Motivation, compliance

Lack of patient's interest Face-to-face contact, regarding

a patient's individual situation

Refusal of the patient, psychiatric and physical comorbidity, formal contra-indication, compliance problems, language problems
Stronger conviction of the

Interest in training of the

needed skills

Good access to the children

at schools

\begin{abstract}
Adherence to lifestyle counselling (dietary and physical activity)
\end{abstract}

physician to implement guidelines

\author{
Compliance, absence \\ of risk factors, \\ comorbidities and \\ disease complications, \\ short duration of the \\ disease
}

Notes: $*$ The CONSORT criteria are according to Moher et al. ${ }^{10}$ Data as far as reported (empty cells: not reported). Subject of prevention: I, Prevention of epidemics and infectious diseases; 2, Lifestyle changes; 3, Cardiovascular risk factors; 4, Cancer; 5, HIV; 6, Osteoporosis; 7, Addiction medicine; 8, Others.

Abbreviations: RCT, Randomised Control Trial; INTS, Intervention Study; NR, Not Reported; PCP, Primary Care Physician; GP, General Practitioner; SD, Standard Deviation; DXA, Dual-Energy X-Ray Absorptiometry (bone densitometry); CAD, Coronary Artery Disease; ABI, Ankle Brachial Index; CAGE, clinical test for the assessment of alcohol-related problems (Cut down, Annoyed, Guilty, Eye-opener).

\section{Barriers from patient's perspective}

We identified 24 studies which reported barriers precluding patients from using screening and prevention services. ${ }^{11,13,14,16,17,19,23,24,29,30,32,36,37,39,43,48,50-56,59}$ The most frequently cited barriers were "the lack of GP's engagement" (5 out of 24), 13,14,32,50,54 "the lack of interest or time"
(8 out of 24), ${ }^{23,43,48,51,53,59}$ and "own disbeliefs" (3 out of 24$){ }^{13,14,19}$

\section{Lack of GP's engagement}

In the patient's view a lack of GP engagement was a common barrier. This referred to the lack of encouragement from 
Table 2 Subjects of prevention

\begin{tabular}{ll}
\hline Subject of prevention & Number of studies $(\mathbf{n}=\mathbf{4 9})$ \\
\hline Prevention of infectious diseases & 12 \\
and epidemics & \\
Lifestyle changes & 12 \\
Cardiovascular prevention & 8 \\
Cancer screening & 4 \\
HIV & 3 \\
Osteoporosis prevention & 2 \\
Addiction medicine & 2 \\
Others & 6 \\
\hline
\end{tabular}

the GP,,$^{13,14,32}$ or missed advice eg, in smoking cessation ${ }^{50}$ or concerning travel medicine. ${ }^{54}$

\section{Lack of interest}

Four studies described a lack of patient interest in physical activity counselling, ${ }^{48,53,59}$ and in smoking and alcohol counselling ${ }^{43,51}$ as a barrier to using preventive services.

Lack of time and own disbeliefs

The lack of time was mentioned as a major barrier in three studies. $^{23,48,53}$

The patients' doubts about the necessity and effectiveness of an influenza vaccination were revealed as barrier in three different studies. ${ }^{13,14,19}$

\section{Facilitators}

The included studies revealed several facilitators to the performance of screening and prevention services both from the GP's and the patient's perspective.

Table 3 The most frequently presented barriers and facilitators

\begin{tabular}{ll}
\hline & Number of studies* \\
\hline GP's perspective & \\
Barriers & 20 \\
Lack of knowledge/skills & II \\
Lack of time/high workload & 9 \\
Own disbelief & \\
Facilitators & 15 \\
Motivation/interest/attitude & 10 \\
Education/knowledge & 7 \\
Feasibility/Usefulness & \\
Patients' perspective & \\
Barriers & 5 \\
Lack of GP's engagement & 5 \\
Lack of patients' interest & 3 \\
Lack of time & 3 \\
Own disbeliefs & \\
Facilitators & 8 \\
Counselling & 5 \\
Conviction/motivation & 4 \\
Feasibility/usefulness &
\end{tabular}

Note: *Multiple responses were possible.

\section{Facilitators from GP's perspective}

Independent of the prevention subject, 43 studies reported any factor which supports GPs to perform preventive activities. ${ }^{11-13,15,19-31,33-37,39-48,50-59}$ Most frequently cited facilitators

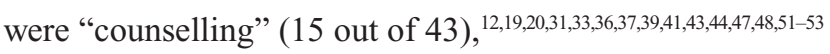
"conviction/motivation" (10 out of 43 ), ${ }^{24,26,33,35,37,41,42,45,50,58}$ and "feasibility/usefulness" (7 out of 43). ${ }^{13,21,22,27,29,48,50,53,55,58}$

\section{Motivation/attitude}

Physicians' acknowledgement of responsibility for prevention and high motivation to implement prevention were the main facilitators in several studies, independent of the main prevention focus (lifestyle changes, ${ }^{48,51-53}$ infectious diseases, ${ }^{12,19,20,36,37}$ cancer screening, ${ }^{31,33}$ and further aspects of prevention ${ }^{41,43,44,47}$ ).

\section{Education/knowledge}

Several studies showed that a specific awareness ${ }^{33}$ and knowledge about a disease, as well as an existing guideline (eg, guidelines on endocarditis prevention ${ }^{24}$ ) or a specific training or educational programmes can increase the probability that the GP will provide prevention services. ${ }^{26,35,37,41,42}$ Also the role of special skills was highlighted in an ophthalmological study in elderly patients in routine ophthalmologic controls to preserve vision as factor that increases specific prevention. ${ }^{45}$

\section{Feasibility/usefulness}

Counselling of inactive patients, ${ }^{48,53,55}$ smokers,${ }^{50}$ and patients using cannabis ${ }^{58}$ was considered as feasible in daily practice. This was considered as a facilitator in using these preventive interventions. Useful tools in chronic disease management (patient education, reminder) ${ }^{29}$ and for identification of patients at atherothrombotic risk (ankle/brachial pressure index $)^{27}$ were also found to be facilitators in performing preventive services.

\section{Facilitators from patient's perspective}

We identified 23 studies describing factors which support

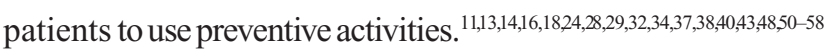
The most frequently cited facilitators were "education/ knowledge" (8 out of 23), 11,14,16,22,24,32,50,54,55 "conviction/ motivation/information" (5 out of 23$)^{28,34,43,48,50,51}$ and “feasibility/usefulness" (4 out of 23). ${ }^{11,13,38,53}$

\section{Counselling}

Information and GP's advice to use screening and preventive services are supporting factors. ${ }^{11,14,16,22,24,32,55}$ Receiving information and advice from a physician was not only an 
important determinant in the decision to receive influenza vaccination ${ }^{11,14}$ but also regarding smoking cessation, or preventive arrangements in the context of travel medicine. ${ }^{50,54}$

\section{Conviction/motivation}

The patient's interest or own initiative (eg, in smoking cessation $^{50,51}$ ) was found to be an important factor in different studies ${ }^{28,34,48}$ Another study showed that the patient's perceived usefulness of tetanus, influenza and pneumococcal vaccination were associated with vaccination status. ${ }^{13}$

\section{Feasibility/usefulness}

A personal proposal suggesting a hepatitis B vaccination by a health care professional was considered as an effective measure to achieve high vaccination coverage. ${ }^{11}$

By a specific intervention (feedback, counselling) one study observed that patients' physical activity could be improved effectively. ${ }^{53}$

\section{Sponsorship/conflicts of interest}

The following papers in our review indicated sponsorship or conflicts of interest, as noted

- Bovier et al: ${ }^{13}$ The research was funded by the Swiss Academy for Medical Sciences and the Federal Office for Public Health (contract no 316.98.6766)

- Cornuz et al:43 One co-author is supported by a Population Health Investigator Award from the Alberta Heritage Foundation for Medical Research and received sabbatical support from the Institute of Social and Preventive Medicine and the Department of Medicine, University of Lausanne

- Eichler et al: ${ }^{25}$ Support by the Helmut Horten Foundation

- Etter et al: ${ }^{51}$ Support by the Health Authority of the Canton of Geneva

- Gasser et al: ${ }^{38}$ Provision of the digital processing system: Merck Sharp and Dohme-Chibret AG Switzerland

- Gauthey et al: ${ }^{14}$ Grant from the President of the State Department for Health and Social Affairs

- Gugelmann et al: ${ }^{15}$ Financial support of the study by SmithKline Beecham corporation

- Hayoz et al: ${ }^{27}$ Support by a grant from Bristol-Myers Squibb and Sanofi-Synthelabo

- Jimmy and Martin: ${ }^{53}$ Financial support by Helsana AG

- Marki et al: ${ }^{55,56}$ Financial support of the study by Health Promotion Switzerland (project 1191)
- Meystre-Agustoni et al: ${ }^{36}$ Sponsoring by the Federal Office of Public Health Page et al: ${ }^{37}$ This study was financed by the Swiss National Science Foundation (Grant no 3346-62449) and by an unrestricted educational grant of Merck Sharp and Dohme-Chibret AG, Glattbrugg, Switzerland

- Pelet et al: ${ }^{40}$ Financial support by the Federal Office of Public Health

- Pichert et al: ${ }^{33}$ Swiss Cancer League (administrative support), Janssen-Cilag AG, Baar (provision of adresses of physicians)

- Sebo et al: ${ }^{57}$ University Hospitals of Geneva, Novartis (subsidiary unrestricted research)

- Stoll et al: ${ }^{39}$ Sponsoring by Roche, MSD, Novartis and Hoechst

- Wunderli et al:22 This study was collaboration between Roche Pharma AG, which made available the reagents free of charge, the Swiss Sentinel Surveillance Network (SSSN), and the Swiss National Influenza Center. The study was funded by grants from Roche Pharma AG and the SSSN.

\section{Discussion}

The study was performed to review all studies with a focus on prevention services in Swiss primary care settings, and to identify barriers and facilitators which influenced physicians in performing and patients in using preventive services.

We could include numerous studies which were conducted in Switzerland during the last twenty years. Taking into account the small number of all studies performed in primary care in Switzerland, the proportion of studies focussing on preventive services is remarkably high. This fact may demonstrate the importance of prevention in primary care, not only in acute or infectious, but also in chronic illnesses. Many studies have shown that preventive activities are an effective way to reduce the burden of chronic illnesses. ${ }^{2,60-62}$ A major finding of our review was that the methodological quality of the available studies is very low. Our results strongly emphasize that future projects should have clearly defined populations, interventions, and outcomes to be able to create valid data about the efficacy but also efficiency of preventive services in primary care.

We identified 49 studies which addressed the prevention of epidemics, lifestyle changes, physical activity counselling, smoking cessation, cardiovascular disease prevention and cancer screening. Included studies revealed several barriers and facilitators in performing screening and prevention activities from GP's as well as from patients' perspective. 
Perceived lack of knowledge/skills, lack of time/high workload and own disbeliefs were the most commonly stated barriers to performing screening and prevention services from the GP's perspective. The lack of GP engagement, lack of interest and time as well as own disbeliefs were the most frequently reported barriers in using preventive activities from the patients' perspective. Two reviews on cancer screening, one specifically on colorectal cancer screening ${ }^{63}$ and one screening for both colorectal and breast cancer ${ }^{64}$ have found very similar barriers, including the GP's disbelief in the usefulness of testing on the physician's side and the lack of recommendation to screen as a barrier from the patient's perspective. A British study on intervention against excessive alcohol consumption showed that GPs report too little training to deal with the problem in everyday practice. ${ }^{65}$ An American study based on a questionnaire about cholesterol treatment revealed an insufficient knowledge and awareness about the treatment goal of non-HDL-Cholesterol. ${ }^{66}$

Both reviews on cancer prevention ${ }^{63,64}$ also revealed the lack of financial coverage by insurance as a major barrier. This problem did not arise in our study since in Switzerland everyone is obliged to have health insurance that also covers many of the mentioned preventive interventions. The following supporting factors in performing preventive services were mentioned by GPs: motivation/attitude, education/ knowledge, feasibility/usefulness. From a patient's perspective, counselling, conviction/motivation and feasibility/ usefulness were the most frequently reported supporting factors for using preventive activities. Similar facilitators such as extent of knowledge or attitude of both the GP and the patient were found in cancer screening. ${ }^{63,64}$ In the US an electronic medical record reminder was found to augment the influenza and pneumococcal vaccination rate. ${ }^{67}$

\section{Sponsorship}

Half of the disclosed sponsorships relate to the pharmaceutical industry and the other half originates in foundations and official authorities. This latter finding suggests that some political efforts are made to support prevention in primary care.

\section{Strengths and limitations}

Our review included a broad variety of studies addressing prevention in primary care over a time period of two decades, but has several limitations. The main limitation is that the methodological quality of the studies is very low. Due to this, conclusions about effective preventive services are not possible.
Furthermore, the focus on the country rather than on a single disease or a disease class precludes clear findings regarding barriers and facilitators.

\section{Conclusion}

Most reviews focussing on screening and prevention activities in primary care addressed vaccination, lifestyle modification and cardiovascular disease prevention. Identified barriers and facilitators indicate a need for primary-care-adapted education and training in prevention which are easy to handle, time saving, and reflect the specific needs of general practitioners. If new prevention programs are to be implemented in general practices, RCTs of high methodological quality are needed to assess their impact.

\section{Disclosure}

The authors report no conflicts of interest in this work.

\section{References}

1. Tengs TO, Adams ME, Pliskin JS, et al. Five-hundred life-saving interventions and their cost-effectiveness. Risk Anal. 1995;15(3):369-390.

2. Sox HC Jr. Preventive health services in adults. $N$ Engl $J$ Med. 1994;330(22):1589-1595.

3. Anderson LM, May DS. Has the use of cervical, breast, and colorectal cancer screening increased in the United States? Am J Public Health. 1995;85(6):840-842.

4. Practice SBoG. The health coach. Available from: http://www. gesundheitscoaching-khm.ch/public/willkommen.php. Accessed December 5, 2011. German.

5. Burack RC. Barriers to clinical preventive medicine. Prim Care. 1989;16(1):245-250.

6. Kottke TE, Brekke ML, Solberg LI. Making "time" for preventive services. Mayo Clin Proc. 1993;68(8):785-791.

7. McPhee SJ, Richard RJ, Solkowitz SN. Performance of cancer screening in a university general internal medicine practice: comparison with the 1980 American Cancer Society Guidelines. J Gen Intern Med. 1986;1(5):275-281.

8. Spitz MR, Chamberlain RM, Sider JG, Fueger JJ. Cancer prevention practices among Texas primary care physicians. J Cancer Educ. 1992;7(1):55-60.

9. Wender RC. Cancer screening and prevention in primary care. Obstacles for physicians. Cancer. 1993;72(Suppl 3):1093-1099.

10. Moher D, Hopewell S, Schulz KF, et al. CONSORT 2010 Explanation and Elaboration: Updated guidelines for reporting parallel group randomised trials. J Clin Epidemiol. 2010;63(8):e1-e37.

11. Birchmeier M, Favrat B, Pecoud A, et al. Improving influenza vaccination rates in the elderly. J Fam Pract. 2002;51(10):856.

12. Bovier PA, Bouvier Gallacdhi M, Chamot E. Swiss primary care physicians reporting of utility and use of recommended vaccinations for adults. Swiss Med Wkly. 2005;135(13-14):192-199.

13. Bovier PA, Chamot E, Bouvier Gallacchi M, Loutan L. Importance of patients' perceptions and general practitioners' recommendations in understanding missed opportunities for immunisations in Swiss adults. Vaccine. 2001;19(32):4760-4767.

14. Gauthey L, Toscani L, Chamot E, Larequi T, Robert CF. Influenza vaccination coverage in the geriatric population of the State of Geneva, Switzerland. Eur J Public Health. 1999;9(1):36-40.

15. Gugelmann RJ, Freed GL, Desgrandchamps D, Diebold P. Hepatitis B vaccination: knowledge and acceptance by Swiss physicians. Soz Praventivmed. 1998;43 Suppl 1:S57-S60, S130-S133. 
16. Hasse B, Moll C, Oehy K, Rothlin M, Krause M. Anti-infectious prophylaxis after splenectomy: current practice in an eastern region of Switzerland. Swiss Med Wkly. 2005;135(19-20):291-296.

17. Matter HC, Cloetta J, Zimmermann H. Measles, mumps, and rubella: monitoring in Switzerland through a sentinel network, 1986-1994. Sentinella Arbeitsgemeinschaft. J Epidemiol Community Health. 1995;49 Suppl 1:4-8.

18. Matter HC, Schmidt-Schlapfer G, Zimmermann H. Monitoring of a whooping cough epidemic 1994/1995 in Switzerland using the sentinel notification system. Sentinella Registry. Schweiz Med Wochenschr. 1996;126(34):1423-1432.

19. Moiradat Rytz S, Chuard C, Regamey C. Vaccination against influenza in the hospital milieu and by family physicians in Fribourg in 1997: facts and opinions. Schweiz Med Wochenschr. 2000;130(10):349-355.

20. Richard JL, Vidondo B, Mausezahl M. A 5-year comparison of performance of sentinel and mandatory notification surveillance systems for measles in Switzerland. Eur J Epidemiol. 2008;23(1):55-65.

21. Vaudaux B, Steinemann MA. General hepatitis B vaccination in Switzerland: what is the attitude of vaccinating physicians? Soz Praventivmed. 1998;43 Suppl 1:S47-S56, S121-S129.

22. Wunderli W, Thomas Y, Muller DA, Dick M, Kaiser L. Rapid antigen testing for the surveillance of influenza epidemics. Clin Microbiol Infect. 2003;9(4):295-300.

23. Brunner-La Rocca HP, Marti B. Significance of after care by family practitioner following myocardial infarct from the patient's viewpoint. Schweiz Rundsch Med Prax. 1993;82(49):1406-1412.

24. Cerletti-Knusel DC, Hoffmann A, Lambrecht JT, Fluckiger U, Zimmerli W. Knowledge and re-evaluation of the prevention of endocarditis in dentistry. Schweiz Monatsschr Zahnmed. 2005;115(5):404-408.

25. Eichler K, Zoller M, Tschudi P, Steurer J. Barriers to apply cardiovascular prediction rules in primary care: a postal survey. BMC Fam Pract. 2007;8:1.

26. Gaspoz JM, Lovis C, Green Y, et al. Do physicians modify their prehospital management of patients in response to a public campaign on chest pain? Am J Cardiol. 1998;81(12):1433-1438.

27. Hayoz D, Bounameaux H, Canova CR. Swiss Atherothrombosis Survey: a field report on the occurrence of symptomatic and asymptomatic peripheral arterial disease. J Intern Med. 2005;258(3):238-243.

28. Muntwyler J, Noseda G, Darioli R, Gruner C, Gutzwiller F, Follath F. National survey on prescription of cardiovascular drugs among outpatients with coronary artery disease in Switzerland. Swiss Med Wkly. 2003;133(5-6):88-92.

29. Götschi AS, Huber F, Weber A. Disease management in patients with coronary heart disease. Ars Medici. 2007;4:160-163. German.

30. Bally K, Martina B, Halter U, Isler R, Tschudi P. Barriers to Swiss guideline-recommended cholesterol management in general practice. Swiss Med Wkly. 2010;140(19-20):280-285.

31. Escher M, Sappino AP. Primary care physicians' knowledge and attitudes towards genetic testing for breast-ovarian cancer predisposition. Ann Oncol. 2000;11(9):1131-1135.

32. Huguenin M, Gutzwiller F, Martin J, Paccaud F, Wietlisbach V. Physical examination in screening for breast cancer: who benefits? Schweiz Med Wochenschr. 1990;120(4):98-104.

33. Pichert G, Dietrich D, Moosmann P, Zwahlen M, Stahel RA, Sappino AP. Swiss primary care physicians' knowledge, attitudes and perception towards genetic testing for hereditary breast cancer. Fam Cancer. 2003;2(3-4):153-158.

34. Praz V, Jichlinski P, Aymon D, Leisinger HJ. Screening of the prostate cancer. "Instantaneous" of a daily practice among 300 general practitioners of the canton of Vaud. Rev Med Suisse. 2005;1(44):2840-2842.

35. Malinverni R, Muller M, Billo NE. HIV infection: survey among practicing physicians in Bern. Schweiz Med Wochenschr. 1992;122(26): 993-1004.

36. Meystre-Agustoni G, Jeannin A, Dubois-Arber F. Prevention practices of primary health care physicians in Switzerland in the context of the HIV/Aids epidemic: changes between 1990 and 2002. Rev Epidemiol Sante Publique. 2007;55(2):87-96.
37. Page J, Weber R, Somaini B, Nostlinger C, Donath K, Jaccard R. Quality of generalist vs specialty care for people with HIV on antiretroviral treatment: a prospective cohort study. HIV Med. 2003;4(3):276-286.

38. Gasser KM, Mueller C, Zwahlen M, et al. Osteoporosis case finding in the general practice: phalangeal radiographic absorptiometry with and without risk factors for osteoporosis to select postmenopausal women eligible for lumbar spine and hip densitometry. Osteoporos Int. 2005;16(11):1353-1362.

39. Stoll BE, Eidenbenz JR, Perrochet F. "Medical audit" of physicians' attitudes on preventing osteoporosis. Rennaz group. Rev Med Suisse Romande. 1999;119(2):145-148.

40. Pelet A, Doll S, Huissoud T, Resplendino J, Besson J, Favrat B. Methadone maintenance treatment in the Swiss Canton of Vaud: demographic and clinical data on 1,782 ambulatory patients. Eur Addict Res. 2005;11(2):99-106.

41. Perdrix A, Decrey H, Pecoud A, Burnand B, Yersin B. Detection of alcoholism in the medical office: applicability of the CAGE questionnaire by the practicing physician. Group of Medical Practitioners PMU. Schweiz Med Wochenschr. 1995;125(38):1772-1778.

42. Bucher HC, Weinbacher M, Gyr K. Influence of method of reporting study results on decision of physicians to prescribe drugs to lower cholesterol concentration. BMJ. 1994;309(6957):761-764.

43. Cornuz J, Ghali WA, Di Carlantonio D, Pecoud A, Paccaud F. Physicians' attitudes towards prevention: importance of intervention-specific barriers and physicians' health habits. Fam Pract. 2000;17(6):535-540.

44. Hausser D, Jeangros C. Prevention in general practice - results of a study of ambulatory health care in the Waadt and Freiburg cantons. Ther Umsch. 1990;47(9):753-758.

45. Peltenburg M, Kiener M, Iseli HP, et al. Preserving vision in the elderly: a survey to start a quality development program in general practice. Praxis (Bern 1994). 2004;93(1-2):9-14.

46. Ramseier F. Our knowledge is patchwork. Survey on the adherence to international guidelines concerning acute and long-term therapy in recurrent depressions and diseases in the schizophrenic field. Praxis (Bern 1994). 1996;85(24):792-797.

47. Steurer-Stey C, Fletcher M, Vetter W, Steurer J. Patient education in asthma: a survey of physicians' knowledge of the principles and implementation of self management in practice. Swiss Med Wkly. 2006;136(35-36):561-565.

48. Allenspach EC, Handschin M, Kutlar Joss M, et al. Patient and physician acceptance of a campaign approach to promoting physical activity: the "Move for Health" project. Swiss Med Wkly. 2007;137(19-20): 292-299.

49. Bovier PA, Sebo P, Abetel G, George F, Stalder H. Adherence to recommended standards of diabetes care by Swiss primary care physicians. Swiss Med Wkly. 2007;137(11-12):173-181.

50. Eckert T, Junker C. Motivation for smoking cessation: what role do doctors play? Swiss Med Wkly. 2001;131(35-36):521-526.

51. Etter JF, Rielle JC, Perneger TV. Labeling smokers' charts with a "smoker" sticker: results of a randomized controlled trial among private practitioners. J Gen Intern Med. 2000;15(6):421-424.

52. Hatz C, Krause E, Grundmann H. Travel advice: a study among Swiss and German general practitioners. Trop Med Int Health. 1997; 2(1):6-12.

53. Jimmy G, Martin BW. Implementation and effectiveness of a primary care based physical activity counselling scheme. Patient Educ Couns. 2005;56(3):323-331.

54. Krause E, Grundmann H, Hatz C. Pretravel advice neglects rabies risk for travelers to tropical countries. J Travel Med. 1999;6(3):163-167.

55. Marki A, Bauer GB, Angst F, Nigg CR, Gillmann G, Gehring TM. Systematic counselling by general practitioners for promoting physical activity in elderly patients: a feasibility study. Swiss Med Wkly. 2006;136(29-30):482-488.

56. Marki A, Bauer GF, Nigg CR, Conca-Zeller A, Gehring TM. Transtheoretical Model-based exercise counselling for older adults in Switzerland: quantitative results over a 1-year period. Soz Praventiv Med. 2006;51(5):273-280. 
57. Sebo P, Abetel G, Stalder H, Bovier PA. Importance of lifestyle counselling by primary care physicians for diabetic patients. Swiss Med Wkly. 2006;136(35-36):566-573.

58. Haller DM, Meynard A, Lefebvre D, Tylee A, Narring F, Broers B. Brief intervention addressing excessive cannabis use in young people consulting their GP: a pilot study. Br J Gen Pract. 2009;59(560):166-172.

59. Schmid M, Egli K, Martin BW, Bauer G. Health promotion in primary care: evaluation of a systematic procedure and stage specific information for physical activity counseling. Swiss Med Wkly. 2009;139(45-46):665-671.

60. Hengstler P, Battegay E, Cornuz J, Bucher H, Battegay M. Evidence for prevention and screening: recommendations in adults. Swiss Med Wkly. 2002;132(27-28):363-373.

61. Kroke A, Boeing H, Rossnagel K, Willich SN. History of the concept of 'levels of evidence' and their current status in relation to primary prevention through lifestyle interventions. Public Health Nutr. 2004;7(2):279-284.

62. Ortegon MM, Redekop WK, Niessen LW. Cost-effectiveness of prevention and treatment of the diabetic foot: a Markov analysis. Diabetes Care. 2004;27(4):901-907.
63. Guessous I, Dash C, Lapin P, Doroshenk M, Smith RA, Klabunde CN. Colorectal cancer screening barriers and facilitators in older persons. Prev Med. 2010;50(1-2):3-10.

64. Vedel I, Puts MTE, Monette M, Monette J, Bergman H. Barriers and facilitators to breast and colorectal cancer screening of older adults in primary care: A systematic review. J Geriatr Oncol. 2011;2(2): 85-98.

65. Wilson GB, Lock CA, Heather N, Cassidy P, Christie MM, Kaner EF. Intervention against excessive alcohol consumption in primary health care: a survey of GPs' attitudes and practices in England 10 years on. Alcohol Alcohol. 2011;46(5):570-577.

66. Virani SS, Steinberg L, Murray T, et al. Barriers to Non-HDL cholesterol goal attainment by providers. Am J Med. 2011;124(9):876-880.

67. Loo TS, Davis RB, Lipsitz LA, et al. Electronic medical record reminders and panel management to improve primary care of elderly patients. Arch Intern Med. 2011;171(17):1552-1558.

\section{Publish your work in this journal}

The International Journal of General Medicine is an international, peer-reviewed open-access journal that focuses on general and internal medicine, pathogenesis, epidemiology, diagnosis, monitoring and treatment protocols. The journal is characterized by the rapid reporting of reviews, original research and clinical studies across all disease areas.
A key focus is the elucidation of disease processes and management protocols resulting in improved outcomes for the patient. The manuscript management system is completely online and includes a very quick and fair peer-review system. Visit http://www.dovepress.com/ testimonials.php to read real quotes from published authors. 